\title{
Konsep Komunitas Arsitektur Perumahan Real Estate: Kaitannya Dengan Konsep Neighborhood dan Modal Sosial
}

\author{
Fernando Siregar ${ }^{1}$, Chandra Tanaka ${ }^{2}$, Andrew Marthin ${ }^{3}$ \\ ${ }^{1}$ Magister Studi Pembangunan, Sekolah Arsitektur, Perencanaan dan Pengembangan Kebijakan, Institut Teknologi Bandung \\ ${ }^{2}$ Master of Engineer, Faculty of Engineering School of Civil Engineering, Universiti Teknologi Malaysia \\ ${ }^{3}$ Aparatur Sipil Negara Pemerintah Daerah Provinsi Lampung \\ *Penulis Korespondensi: ssfernandoarchi54@gmail.com; Telp. +6281220034009
}

\begin{abstract}
Abstrak:
Menjauhnya jarak antara fisik pemukiman dengan karakter sosialnya merupakan cerminan dari minimnya interaksi sosial yang terjadi diantara penghuni perumahan yang dapat menciptakan hubungan sosial dalam konsep neighborhood. Penelitian ini dirancang untuk mengkaji, memahami praktik-praktik interaksi sosial yang bisa mencerminkan modal sosial dan untuk memahami apakah masyarakat real estate merupakan sebuah komunitas. Penelitian ini menggunakan metode kualitatif - deskriptif - eksploratif dengan pendekatan studi kasus pada salah satu perumahan menengah atas di Bandung. Hasil penelitian menunjukkan tidak adanya unsur konsep neighborhood pada arsitektur perumahan, menjadi pengaruh dalam menghambat perkembangan jaringan sosial penghuninya sehingga tidak menimbulkan hubungan timbal balik dalam konsep komunitas. Ruang-ruang publik belum dapat berkontribusi secara maksimal dalam mewadahi praktik interaksi sosial. Interaksi yang membentuk jaringan sosial antar penghuni terjadi berdasarkan persamaan keyakinan yang diwadahi pada fasilitas keagamaan. Karakter interaksi sosial antar penghuni belum mampu membentuk unsur-unsur modal sosial sehingga tidak dapat mewujudkan konsep komunitas yang solid. Disimpulkan beberapa unsur yang menjadi hambatan terbentuknya modal sosial bagi komunitas penghuni arsitektur perumahan, diantaranya: kepercayaan (trust), dilema waktu (time dilemma), ketergantungan sosial (social dependence), kepedulian sosial (social care), norma (norms) dan jejaring (network). Keenam unsur tersebut menjadi faktor lemahnya proses pembentukan modal sosial pada perumahan real estate.
\end{abstract}

Kata Kunci: arsitektur perumahan, konsep komunitas, konsep neighborhood, modal sosial, real estate.

\section{Latar Belakang}

Jumlah hunian sebagai salah satu kebutuhan utama manusia meningkat seiring pertambahan penduduk. Lingkungan perumahan yang bertumbuh pesat di Kota Bandung sebagai tempat hidup keseharian masyarakat seharusnya menjadi tempat yang bermakna serta signifikan dalam menciptakan modal sosial bagi penghuninya. Perkembangan komersialisasi hunian sudah sangat disadari dimata masyarakat Kota Bandung. Yang menjadi dasar pertanyaan kemudian adalah seberapa jauh kohesifitas permukiman dapat tercipta dalam hunian baik sebagai hunian individual atau kelompok. Dalam tradisi permukiman Indonesia, hunian maupun kelompok hunian mencerminkan sebuah kohesifitas sosial dari masyarakat penghuninya. Namun, fakta-fakta yang terkemuka justru menunjukkan kian menjauhnya jarak antara fisik pemukiman dengan karakter sosialnya. Hal ini merupakan cerminan dari minimnya interaksi sosial yang terjadi diantara penghuni perumahan yang dapat menciptakan hubungan sosial dalam konsep neighborhood.

Tanpa disadari, terjadi fenomena perilaku sosial kurang baik yang merupakan dampak dari kumpulan hunian/ perumahan (spacial). Tata letak lingkungan perumahan dan permukiman urban mengalami problematika sosial-spasial hingga lekat terhadap pembangunan mutu karakter sumber daya manusia yang tidak berkembang. Lingkungan perumahan yang bertumbuh pesat di Kota Bandung sebagai tempat hidup keseharian masyarakat seharusnya menjadi tempat yang bermakna serta signifikan dalam menciptakan modal sosial bagi penghuninya. Dalam kehidupan sehari-hari sikap empati dan solidaritas sosial atas sesama seolah menjadi fenomena yang sangat mahal dan bukan tidak mungkin adalah salah satu penyebab apatisme yang menyebabkan terjadinya konflik sosial-spasial, kekerasan, kerusuhan, kriminalitas yang akan melekat pada perilaku keseharian masyarakat. Kecenderungan menurunnya harkat dan martabat kota adalah akibat berantakannya struktur sosial, perkembangan segregasi spasial yang mempunyai kecenderungan untuk memisahkan diri dari masyarakat - sosial, menipisnya kekentalah komunitas atau pola paguyuban. 
Fokus penelitian ini mendeskripsikan dan mengeksplorasi kondisi sosial penghuni yang terbentuk oleh lingkungan arsitektur perumahan real estate terhadap suatu perilaku kebersamaan, kepedulian dalam sebuah komunitas hunian yang dapat menjadi sebuah modal sosial. Munculnya fenomena beberapa real estate yang sudah memberikan fasilitas sosial/ ruang-ruang publik namun apakah dapat menjadi sarana interaksi sosial bagi penghuninya atau kurangnya penggunaan ruang-ruang tersebut sebagai wadah interaksi sosial. "Masyarakat modern banyak menarik diri, meminimalkan kontak dengan lingkungan, dan bahkan beranggapan yang diluar rumah adalah musuh." (Arcana \& Prasetya.2006 dalam Barliana.2010). Penelitian ini bertujuan untuk memahami praktik-praktik interaksi sosial yang bisa mencerminkan modal sosial dan untuk memahami apakah masyarakat real estate merupakan sebuah komunitas. Pertanyaan penelitian, yaitu; (1) Bagaimana praktik interaksi sosial arsitektur yang terjadi dalam suatu perumahan masyarakat real estate yang ditunjang dengan lingkungan ber-arsitektur? (2) Bagaimana cara masyarakat mewadahi interaksi sosial? Apakah ruang-ruang interaksi itu tersedia? Apakah ruang interaksi tersebut digunakan? dan terjadi interaksi sosial? (3) Seperti apa karakter interaksi sosial pada real estate?

\section{Kajian Literatur}

Berdasarkan persoalan tersebut, interaksi sosial termasuk hal yang penting dalam mempengaruhi kualitas hidup manusia. Masyarakat dalam perumahan komersil real estate cenderung bersifat individualis, dengan tingkat privasi yang tinggi. Faktor-faktor tersebutlah yang menjadi salah satu unsur konflik sosial pada sebuah struktur sosial komunitas penghuni real estate. Permukiman dan segala fasilitasnya sebagai fenomena sosial-spasial yang mewadahi interaksi sosial diantara penghuni perumahan menjadi kontributor utama untuk mendorong terwujudnya modal sosial dalam sebuah konsep ketetangaan (neighborhood) yang ideal. Komunitas didefinisikan sebagai orang-orang yang bertempat tingal di suatu daerah yang terbatas secara geografis, yang terlibat dalam interaksi sosial dan memiliki satu atau lebih ikatan psikologis satu dengan yang lain dan dengan wilayah tempat tinggalnya. Dalam konsep komunitas mengandung empat komponen, yaitu: (1) Manusia (people); (2) Dibatasi Wilayah Geografis; (3) terlibat dalam interaksi sosial; (4) ikatan psikologis antara satu sama lain dengan tempat tinggal. (Christenson \& Robinson.1980).

Modal sosial merupakan sesuatu yang sangat penting dalam kehidupan sosial komunitas, karena: memberikan kemudahan dalam mengakses informasi bagi anggota komunitas, menjadi media power sharing atau pembagian kekuasaan, mengembangkan solidaritas, memungkinkan mobilisasi sumber daya, memungkinkan pencapaian tujuan bersama, dan membentuk perilaku kebersamaan dalam organisasi komunitas. (Lesser.2000). Modal sosial adalah kemampuan para individu dalam beraktivitas secara tepat untuk mencapai tujuan bersama di dalam komunitas atau organisasi (Fukuyama.1995). Unsur-unsur modal sosial (Bourdieu.1986, Coleman. 1990, Putnam.2002, Fukuyama.1995) digambarkan kedalam lima hal, yaitu: trust (saling percaya), norms (norma), networks (Jaringan), reprocity (hubungan timbal balik).

Ketetanggaan (neighborhoods) didefinisikan sebuah daerah yang dibatasi beberapa jalan dan perhitungan secara statistik dimana orang dapat berinteraksi satu sama lain untuk kedekatan mereka (Taylor.1982). Hubungan tetangga didirikan pada kedekatan dan lokalitas bersama, hubungan bertetangga dicirikan oleh ketersediaan, keramahan ditambah dengan rasa hormat terhadap privasi dan pemahaman tentang potensi menolong. Tujuan utama dari tetangga adalah menawarkan bantuan untuk tugas-tugas sesekali seperti berbelanja; memberikan bantuan darurat; dan, mempertahankan kehadiran yang mengganggu atau memantau di lingkungan sekitar. Tetangga, juga memainkan peran penting, yang sering diabaikan, dalam komunitas. Mereka membentuk, dalam banyak kasus, sistem pemantauan informal; memberikan bantuan yang diperlukan pada tingkat ketergantungan yang lebih rendah dan mereka yang paling mungkin melakukan intervensi pada saat krisis. Mereka juga menyediakan tautan penting ke komunitas yang lebih besar dan tidak jarang ke penyedia layanan (Wenger.1990). Ketetanggaan diuraikan dalam enam fungsi (Evans:1982), yaitu: (1) Interaksi sosial; (2) kontrol sosial; (3) Perasaan aman dan tenteram bagi penduduk; (4) Identitas kolektif dan perasaan tentang tempat; (5) Sosialisasi.

Perumahan merupakan tempat tiap individu yang ada saling berinteraksi dan mempengaruhi satu sama lain serta memiliki sense of belonging atas lingkungan tempat tinggalnya (Abrams. 1964). Permukiman dibuat untuk memuaskan manusia termasuk kepuasan dalam hal ekonomi, sosial, politik, teknologi dan budaya dan sebaliknya permukiman terbentuk dari kekuatan sosial, ekonomi, politik, ideology dan lainnya yang dirangkum kedalam suatu teori yaitu Teori Ekistics (Doxiadis. 1967). Real estate didefinisikan sebagai suatu kawasan tanah yang dikuasai oleh raja, bangsawan dan landlord (tuan tanah pada jaman feodal diabad pertengahan), atau singkatnya properti milik kerajaan (Kiyosaki.1998).

Ruang publik didefinisikan sebagai ruang di mana setiap individu dapat masuk dan turut serta dalam percakapan tanpa tekanan dari pihak lain (Habermas.1962). Ruang ini menjadi tempat berkumpul dan pusat berbagai aktivitas manusia yang akan meningkatkan kualitas lingkungan fisik dan sosialnya sendiri. Keberadaan ruang publik menjadi unsur yang penting pada neighborhood karena salah satu dasar terbentuknya neighborhood 
itu sendiri adalah interaksi sosial di antara penghuninya, yang sebagian besar terjadi di ruang publik (Rubenstein.1992). Terjadinya aktivitas sosial di ruang publik berkaitan erat dengan keadaan fisik lingkungannya. Pengaturan fisik dapat mendukung atau mencegah terjadinya kontak audio dan visual setidaknya dalam lima cara yaitu:

Tabel 1. The Sense and Communication. Pengaturan fisik dapat mendorong atau mencegah kontak visual dan pendengaran setidaknya dalam lima cara berbeda. (Gehl. 1987).

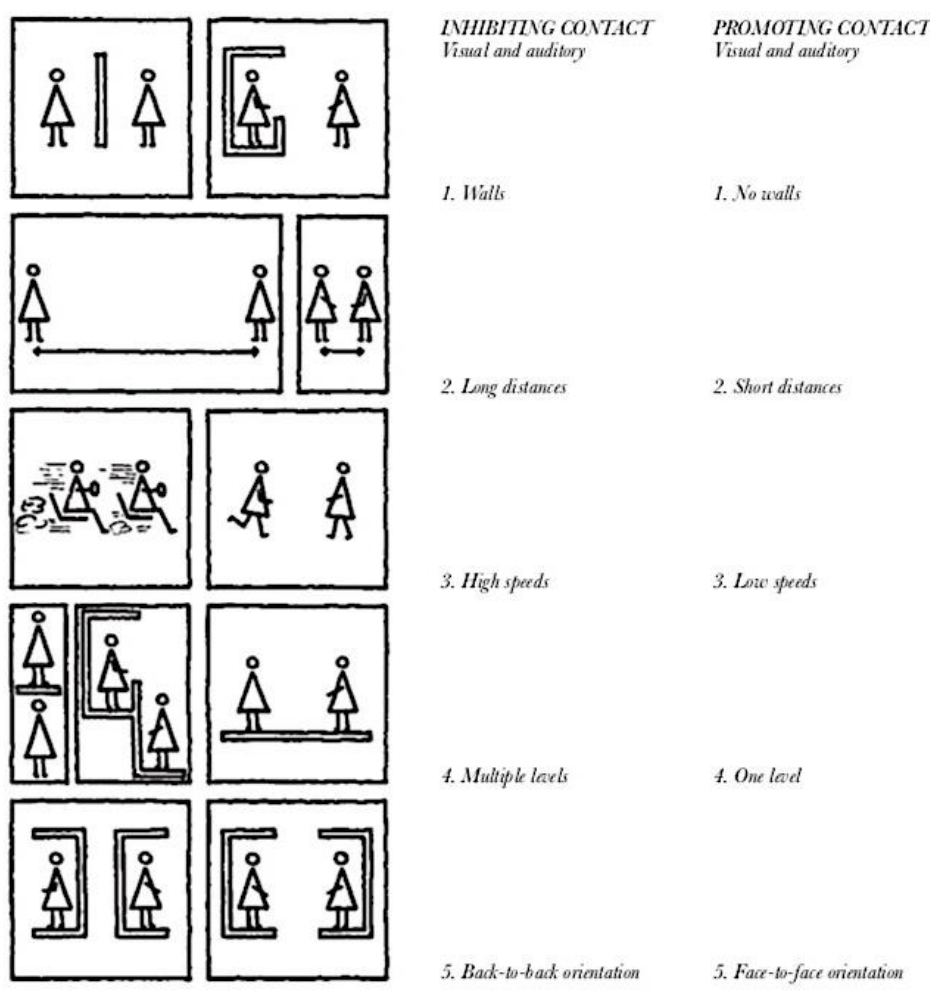

Pengaturan-pengaturan secara fisik tersebut dapat menciptakan metode-metode perancangan arsitektur yang akan mempengaruhi ruang publik dalam kaitannya dengan kondisi sosial yang ingin dicapai dalam suatu neighborhood

\section{Metode}

Untuk menjawab pertanyaan penelitian, penelitian menggunakan metode kualitatif deskriptif-eksploratif, dengan pendekatan studi kasus pada salah satu perumahan real estate di Bandung. Dengan melakukan pengumpulan data, analisis, dan menarik kesimpulan berdasarkan hasil analisis. Penelitian kualitatif (Creswell. 1998) adalah sebuah proses penyidikan, pemahaman berdasarkan tradisi metodologi penelitian yang berbeda yang mengeksplorasi masalah sosial atau manusia. Menyajikan setiap kata-kata pandangan informan dalam wawancara secara terperinci tentang situasi sosial dan mengklasifikasikan berdasarkan isu dengan menggunakan teknik coding.

\subsection{Metode Pengumpulan Data}

Pengumpulan data penelitian diperoleh melalui dua jenis metode yakni data sekunder (studi kepustakaan) dan data primer (pengamatan lapangan). Pengumpulan data primer di lakukan ke dalam dua metode, yaitu: (1) Pengamatan (observasi), dilakukan dengan mengamati pola-pola perilaku interaksi sosial yang terjadi pada rutinitas hari kerja dan hari libur yang dilakukan pada fasilitas umum dan fasilitas sosial (ruang publik, tempat ibadah); (2) Wawancara, dilakukan kepada beberapa elemen yang terkait dengan perilaku penghuni perumahan yang dikelompokkan sebagai penghuni perumahan, pengurus lembaga sosial, institusi non formal (security) dan masyarakat non penghuni. Validasi data dilakukan dengan teknik triangulasi, yaitu dengan mengecek data hasil wawancara, pengamatan dan penelusuran dokumen. Selanjutnya, analisis data yang diklasifikasi berdasarkan isu permasalahan dan dibahas sesuai pertanyaan penelitian dan hasil kajian literatur. 


\section{Hasil dan Pembahasan}

\subsection{Pola Interaksi Penghuni Perumahan Cluster E.}

Perkembangan kondisi sosial yang ada di perumahan real estate terjadi dan terbentuk akibat kondisi lingkungannya yang diuraikan kedalam beberapa aspek. Aspek pertama interaksi sosial. Para penghuni cenderung membatasi interaksi agar menghindari terjadinya kontak sosial yang negatif, dimana dapat mengakibatkan timbulnya pertentangan yang dapat membawa keterangan-keterangan sosial, membentuk sebuah resiko terjadinya konflik sosial. Komunikasi yang terbentuk oleh penghuni seolah untuk menjaga keharmonisan ketetanggaan agar dapat berlangsung dalam waktu yang panjang tanpa kesan yang negatif. Namun dalam pembatasan itu, pemupukan kepercayaan (Trust) antar penghuni yang heterogen dan proses perkembangan jaringan (networks) yang menimbulkan hubungan timbal balik (reciprocity) pun menjadi stagnan (tidak berkembang). Sifat individual diidentifikasikan melalui minimnya kontribusi dalam menyelesaikan masalah bersama yaitu fasilitas umum lingkungan. Hal tersebut terukur saat ada penghuni yang tidak ikut berkontribusi untuk perbaikan jalan komplek didepan rumahnya sebagai fasilitas umum.

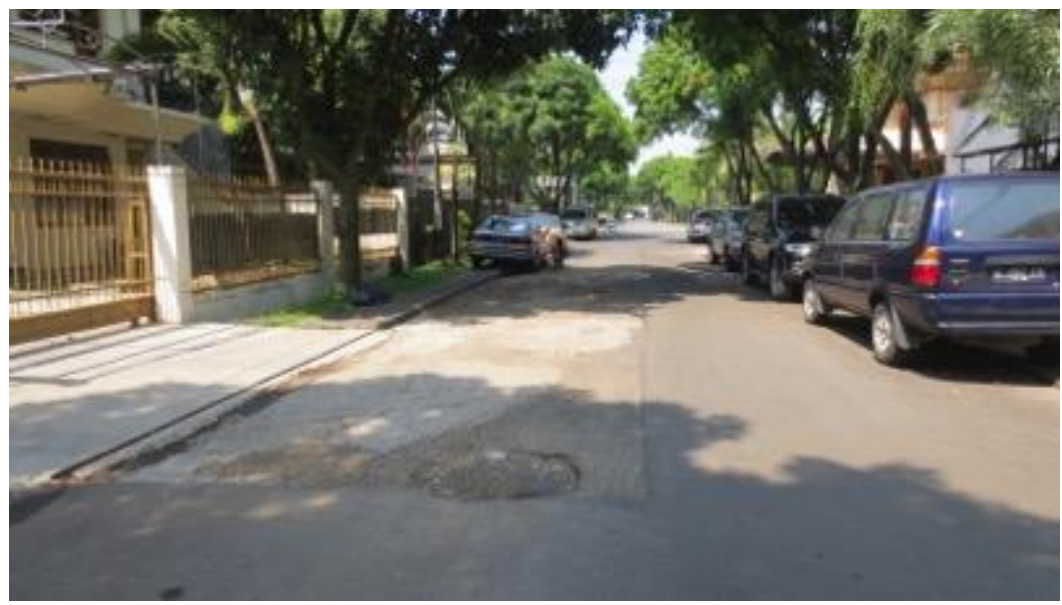

Gambar 1. Kondisi Jalan Perumahan Cluster E.

Aspek kedua kegiatan rutinitas. Tingkat kegiatan rutinitas penghuni yang mayoritas adalah pengusaha cenderung sangat tinggi, sehingga waktu menjadi sebuah batas dan sekaligus menjadi hambatan terjadinya interaksi yang dapat membangun jaringan sosial antar penghuni perumahan.

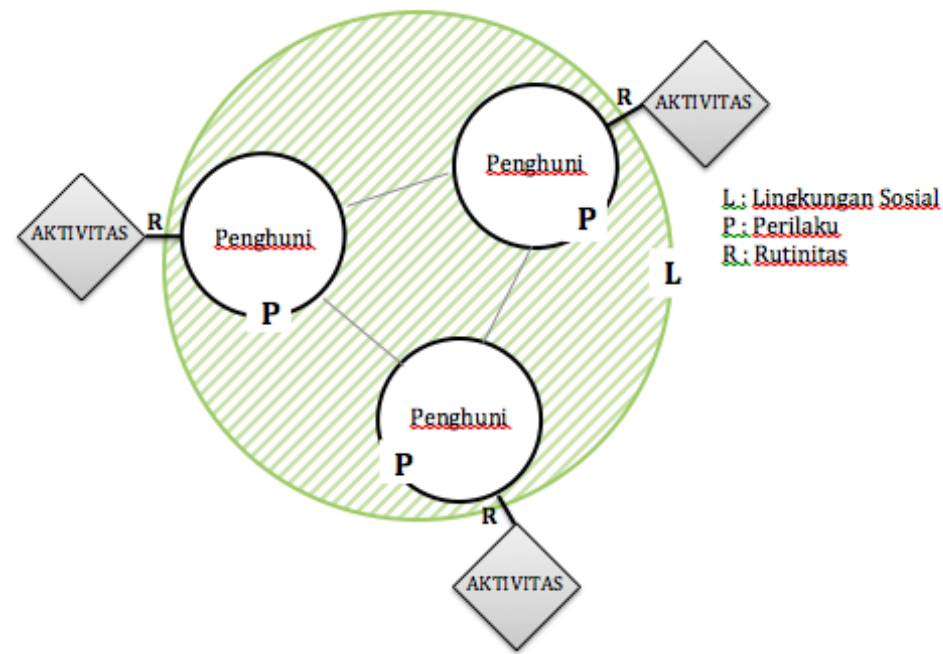

Gambar 2. Pola Hubungan Ketetanggaan Penghuni Cluster E.

Interaksi sosial penghuni perumahan pada umumnya hanya terjadi pada batas langsung rumah penghuni yang berhadapan atau bersebelahan (batas depan, batas samping kiri dan samping kanan) maka akan selalu membentuk pola segitiga antar perilaku penghuni (P). Pola perilaku penghuni (P) memiliki batasan yang ditandai dengan garis hitam tebal solid merupakan batas fisik arsitektur rumah (elemen pagar dan fasad). Elemen fisik arsitektur tersebut membatasi intensitas interaksi sosial antar penghuni dilambangkan sebagai garis lurus tipis yang menghubungkan 
antar penghuni (P), interaksi yang sangat jarang dan secara umum bentuk interaksi terjadi berdasarkan kejadian-kejadian spontan/ tanpa disengaja (pada saat berpapasan). Garis hitam tebal yang menghubungkan penghuni dengan aktivitas menandakan intensitas kegiatan yang sangat tinggi, lebih sering dilakukan dan menghabiskan banyak waktu diluar lingkaran besar (L) lingkungan arsitektur Cluster E. Jarangnya interaksi antar penghuni yang terjadi pada lingkungan arsitektur cluster E membuat jarak lingkaran penghuni (P) semakin jauh. Ruang-ruang publik yang ada dalam lingkungan arsitektur cluster E sangat jarang digunakan oleh penghuni sebagai wadah dalam melaksanakan aktivitas sosial yang dapat menimbulkan interaksi sehingga lingkaran penghuni (P) seharusnya dapat beririsan satu sama lain membentuk irisan yakni ikatan sosial yang terbentuk akibat interaksi antar penghuni dalam arsitektur lingkungan cluster E.

\subsection{Pola Interaksi Penghuni Cluster E. Dilihat Dari Sudut Pandang Lembaga Sosial (RT)}

Perkembangan kondisi sosial berdasarkan sudut pandang lembaga sosial pada Cluster E. diuraikan kedalam beberapa aspek. Aspek pertama interaksi sosial. Lembaga Sosial (RT) sekaligus sebagai penghuni justru beranggapan bahwa minimnya interaksi yang terjadi antar penghuni seolah memang disengaja untuk menghindari bentuk interaksi sosial bersifat negatif dapat membawa keterangan-keterangan sosial, privasi masing-masing warga, pada akhirnya dapat mengurangi kepercayaan antar penghuni.

Aspek kedua adalah estetika dan fungsi arsitektur rumah. Beberapa penghuni real estate cenderung mendahulukan kepentingan pribadi, tanpa memperhatikan dampak lingkungan yang dialami tetangganya. Hal ini dibuktikan melalui penerapan elemen material estetik arsitektur pada dinding batas langsung dengan tetangga yang gagal konstruksi sehingga merugikan tetangga disebelahnya, kejadian tersebut tidak berakhir pada tanggungjawab dan penyelesaian permasalahan secara kekeluargaan. Status sosial manusia, ras. suku dan keyakinan bukan menjadi faktor seseorang untuk antipati terhadap struktur sosial, tetapi social learning yang terbentuk sejak kecil membuat seseorang mempunyai modal sosial dalam kehidupannya. Hal ini tercermin pada perilaku beberapa penghuni real estate yang mencerminkan sikap yang tidak taat pada norma sosial yang berlaku. Tidak adanya pengendalian sosial oleh penghuni dan lembaga sosial yang berbentuk kontrol maupun sanksi sosial bagi pelaku yang melanggar norma-norma bersama tadi, maka tidak heran akan menjadi bentuk peniruan bagi penghuni lainnya untuk mengabaikan norma-norma bersama demi terwujudnya kepentingan individu.

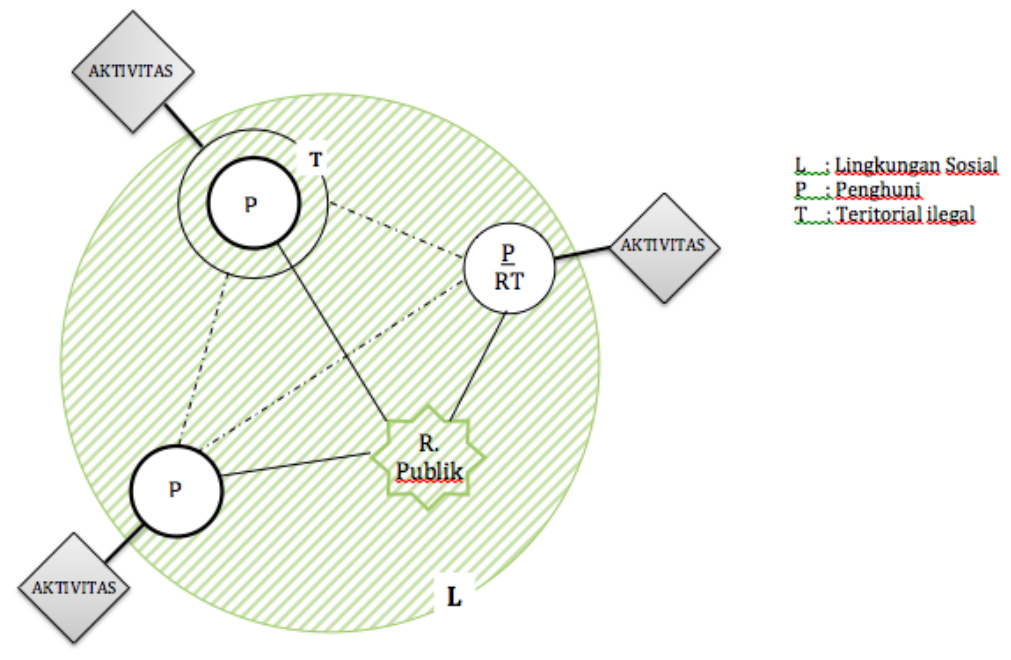

Gambar 3. Pola Hubungan Ketetanggaan Dari Sisi Lembaga Sosial (RT).

Garis putus-putus sebagai konektivitas jaringan antar penghuni merupakan bentuk interaksi yang terjadi secara spontanitas dan bersifat insidentil. Secara umum interaksi dilakukan hanya pada saat penghuni melakukan aktivitas proses atau aktivitas penting, sangat jarang terlihat aktivitas pilihan yang terjadi dalam lingkungan Custer E (L). Garis lurus solid yang menghubungkan konektivitas antar penghuni merupakan bentuk hubungan antar penghuni yang terjadi akibat keberadaan ruang publik pada Cluster E. Perkembangan konektivitas jaringan sosial antar penghuni terhambat oleh tingkat rutinitas aktivitas penghuni yang sangat tinggi (sering) dilakukan diluar lingkungan perumahan dan terhambat oleh pelanggaran akan norma-norma yang terjadi oleh beberapa penghuni yang menggunakan fasilitas umum dan ruang publik sebagai area teritorial ( $\mathrm{T}$ ) yang bersifat individu sehingga mengusik kenyamanan penghuni lainnya serta tidak diikuti oleh pengendalian sosial yang berbentuk sanksi-sanksi Hal tersebut lah yang memicu tidak terjadinya hubungan timbal balik yang menimbulkan ikatan sosial antar penghuni maupun lembaga sosial yang ada. 


\subsection{Pola Interaksi Penghuni Perumahan Cluster $P$}

Perkembangan kondisi sosial yang ada di Cluster P. terjadi dan terbentuk akibat kondisi lingkungannya yang diuraikan kedalam beberapa aspek. Aspek pertama adalah interaksi sosial. Kontak sosial dalam bertetangga bukan hal utama bagi kehidupan penghuni dalam bertetangga. Hal ini dilihat dari jaringan relasi penghuni yang dijalin hanya dengan tetangga yang berbatasan langsung dengan rumahnya. Interaksi tersebut pun terjadi hanya berdasarkan tujuan tertentu, kontak sosial yang bersifat primer namun tidak mempererat jalinan kerjasama yang membawa manfaat kepada kehidupan sosialnya. Tidak aktif dalam suatu komunitas sosial yang ada dalam lingkungan perumahan memang merupakan hal yang dihindari penghuni untuk mencegah kontak sosial negatif menghindari keterangan-keterangan sosial tetangga yang belum tentu riil sehingga keharmonisan bertetangga untuk kurun waktu yang lama tetap terjaga. Namun dampak dari hal tersebut kehidupan sosial dalam bertetangga terkesan tawar, tidak membentuk hubungan timbal balik antar penghuni.

Aspek kedua multikultur. Masyarakat yang terdiri dari perbedaan ras dan agama mempunyai peran dalam terjadinya interaksi sosial antar penghuni, jenis fasilitas pendidikan yang berada di dalam komplek perumahan seolah hanya untuk memfasilitasi masyarakat mayoritas dengan keyakinan agama tertentu. Dalam suatu perumahan yang heterogen terdiri penghuni dengan berbagai macam latar belakang, ras, agama, pembagian fasilitas-fasilitas yang tidak berimbang menjadi titik awal pecahnya hubungan timbal balik antar penghuni yang berkeyakinan berbeda.

Aspek ketiga adalah keamanan. Tingkat kriminalitas yang semakin tinggi membuat penghuni membutuhkan rasa aman dan nyaman. Pagar berfungsi sebagai pelindung dari ancaman bahaya yang datangnya dari luar agar tetap mendapatkan rasa aman. Disaat penghuni menjadikan pagar dengan konsep tertentu yakni sebagai aksen dan menjadi status jati diri arsitektur (semakin tinggi dan besar pagar maka semakin terkesan kokoh), Namun secara tidak sadar pagar yang juga berfungsi sebagai batas teritorial justru berkontribusi batas fisik yang terurai sebagai batas sosial untuk menghindari kontak sosial antar sesama penghuni.

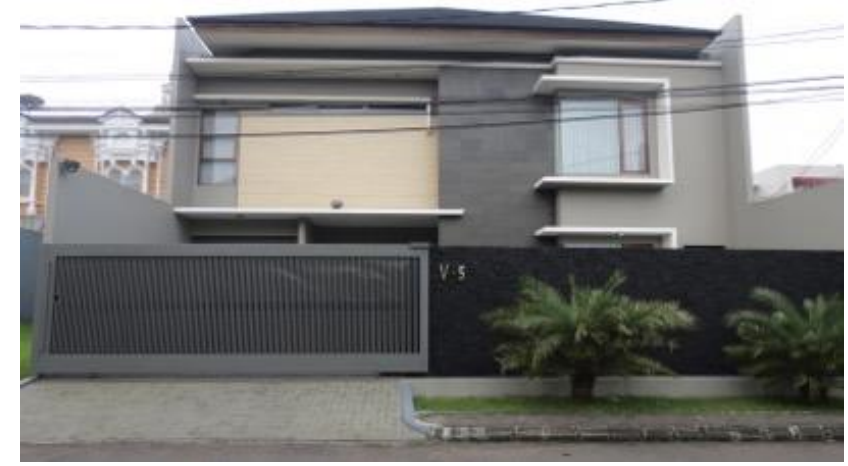

Gambar 4. Elemen Pagar Yang Tinggi dan Menutupi Fasade Bangunan.

Manusia sekarang cenderung memilih lingkungan yang aman meski menyampingkan struktur sosial yang terjadi akibat dari penampilan arsitektur rumah. Hal tersebut menjadi salah satu faktor minimnya kepercayaan antar penghuni dimana individu tertentu akan menimbulkan masalah bagaimana mengamankan identitasnya sebagai manusia, masyarakat dan sebagai penganut tradisi kebudayaan tertentu dari tradisi kebudayaan penghuni lainnya.

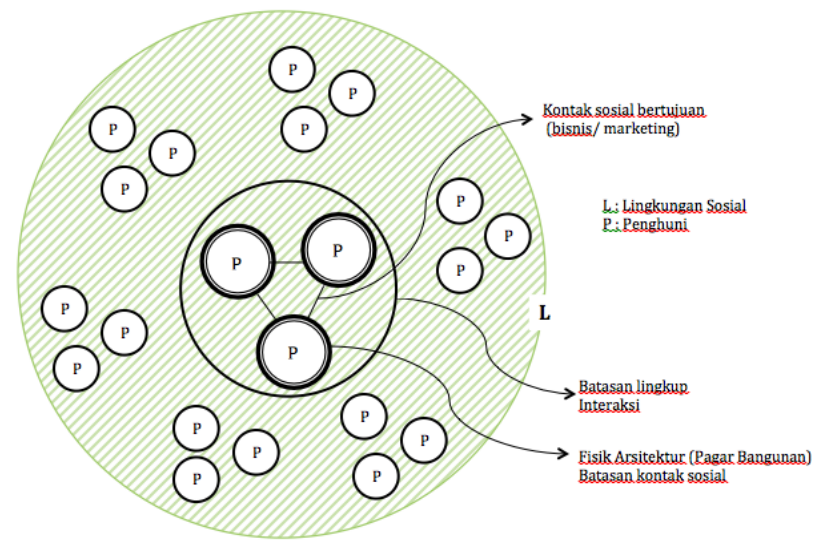

Gambar 5. Pola Hubungan Ketetanggaan Penghuni Perumahan. 
Pola interaksi antar penghuni membentuk pola segitiga yang terjadi akibat kontak antar penghuni (P) akibat batas rumah yang bersinggungan langsung (batas depan, batas samping kiri dan kanan). Secara sadar pola interaksi tersebut menjadi batasan bagi penghuni untuk tidak melakukan interaksi dengan tetangga lainnya yang rumahnya tidak bersinggungan atau berdekatan karena merasa tidak dekat dan tidak kenal jadi tidak harus melakukan interaksi pada saat bersinggungan dalam satu lingkungan arsitektur Cluster P. Faktor ini menjadi salah satu hambatan bagi perkembangan jaringan sosial antar penghuni. Selanjutnya fisik arsitektur rumah yang menggunakan elemen pagar sebagai konsep keamanan dan estetika fasad justru menjadi batas fisik yang nyata untuk mencegah peluang interaksi sosial terjadi antar penghuni perumahan.

\subsection{Pola Interaksi Penghuni Dilihat Dari Sudut Pandang Lembaga Sosial (RT)}

Perkembangan kondisi sosial berdasarkan sudut pandang lembaga sosial pada Cluster P diuraikan kedalam beberapa aspek. Aspek pertama adalah peran Pemerintah. Peran Pemerintah dalam menciptakan ruang interaksi yang baik sangat rentan, mengingat masyarakat perumahan real estate yang rata-rata memiliki tingkat rutinitas yang tinggi sehingga peran pemerintah berfungsi sebagai sarana menyadarkan masyarakat tunduk pada persyaratan-persyaratan, aturan untuk tinggal dalam kompleks perumahan. Dampak positif dari peran pemerintah mampu berkontribusi dalam meningkatkan peluang agar terbentuknya interaksi sosial antar penghuni perumahan melalui lembaga sosial didalamnya (Rukun Tetangga) sebagai koordinator interaksi antara warga.

Aspek kedua adalah multikultur. Dalam kehidupan sosial penghuni tidak terjadi proses asimilasi yang membentuk akulturasi, namun bentuk interaksi sosial masyarakat perumahan hanya terjadi berdasarkan persamaan keyakinan yang dianut, berkumpul pada waktu-waktu tertentu untuk melaksanakan kegiatan-kegiatan keagamaan

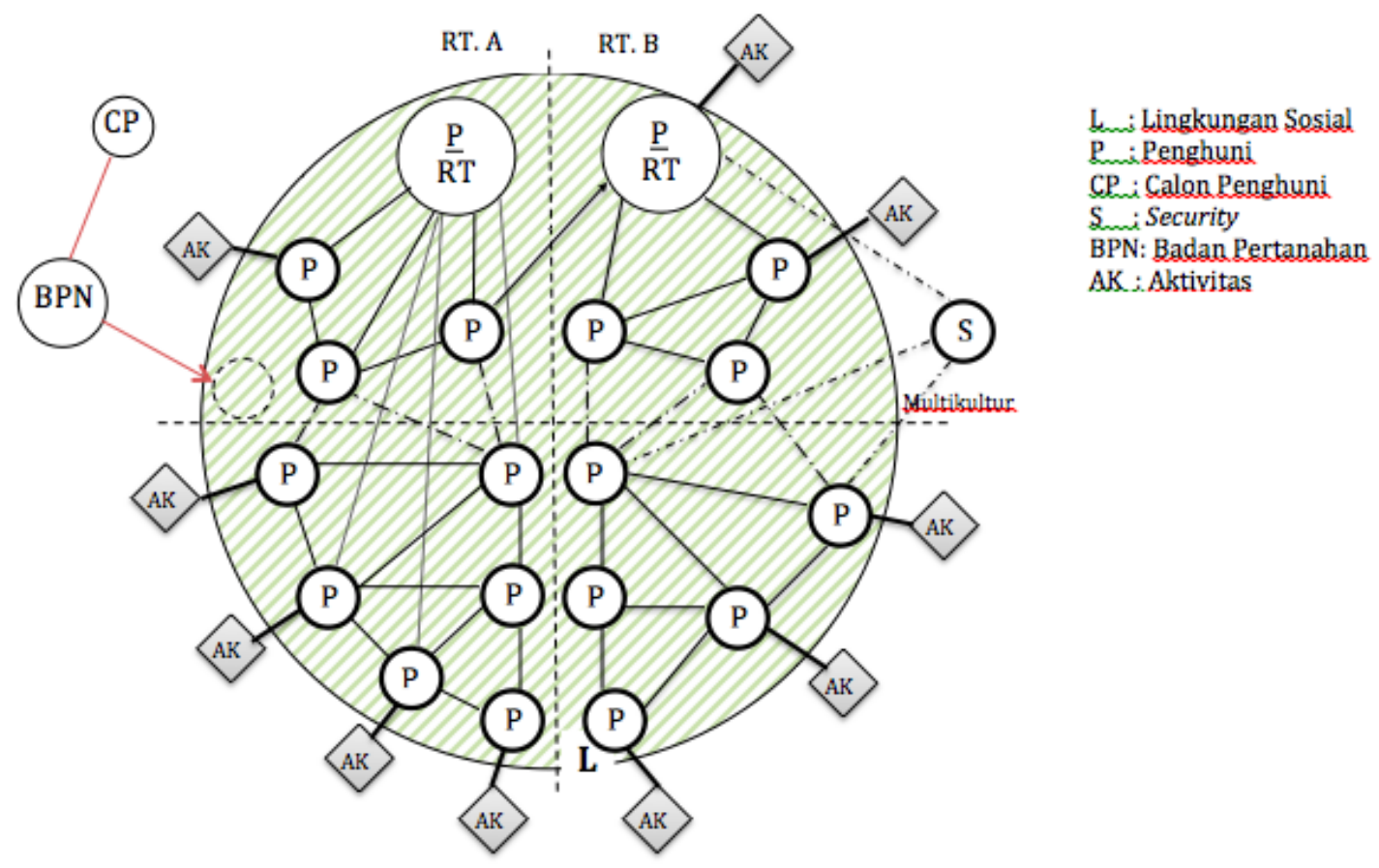

Gambar 6. Pola Hubungan Ketetanggaan Sudut Pandang Lembaga Sosial (RT).

Pada Rukun Tetangga A dan B, bentuk interaksi yang terjadi antar penghuni berdasarkan persamaan terhadap suatu keyakinan, dan interaksi tersebut umumnya terjadi pada tempat-tempat ibadah sesuai dengan kepercayaan masing-masing. Minimnya kepercayaan antar penghuni yang berbeda keyakinan untuk melakukan interaksi membuat perkembangan jaringan sosial terhambat. Pola hubungan ketetanggan dibagi oleh garis horisontal yang membedakan penghuni sesuai dengan kepercayaannya. Perkembangan jaringan sosial yang terjadi oleh faktor persamaan keyakinan itupun dihambat oleh minimnya waktu untuk berinteraksi antar sesama penghuni akibat tingkat kesibukan masing-masing penghuni. Hal tersebut menjadi hambatan bagi lembaga sosial untuk melakukan pengendalian sosial. Lebih lanjut Badan Pertanahan Negara mempunyai peran untuk membentuk pola interaksi dan pengendalian sosial oleh lembaga sosial terhadap penghuni perumahan khususnya Cluster P. BPN diharapkan mengeluarkan dan memantau penuh kebijakan agar setiap calon penghuni yang akan membeli tanah di perumahan wajib melakukan koordinasi terlebih dahulu dengan lembaga sosial (RT) setempat agar kedepannya memudahkan lembaga sosial untuk mengenal seluruh warganya yang nantinya akan sangat mudah bagi pengurus lembaga sosial untuk melaksanakan pengendalian sosial pada warganya. Aktivitas kegiatan diluar lingkungan perumahan yang 
sangat tinggi juga merupakan salah satu faktor minimnya pengendalian sosial yang dilakukan oleh lembaga sosial setempat hal inilah yang menghambat perkembangan jaringan sosial antar lembaga sosial dan penghuninya. Jaringan antara lembaga sosial (P/RT) dan penghuni (P) digambarkan sebagai garis putus-putus yang dikoneksikan oleh institusi non formal (security) sebagai mediator. Potensi lain adalah jarak, jarak fisik arsitektur antar rumah yang cukup jauh dan dibatasi oleh pagar menjadi salah satu alasan para penghuni untuk tidak melakukan interaksi dengan tetangganya.

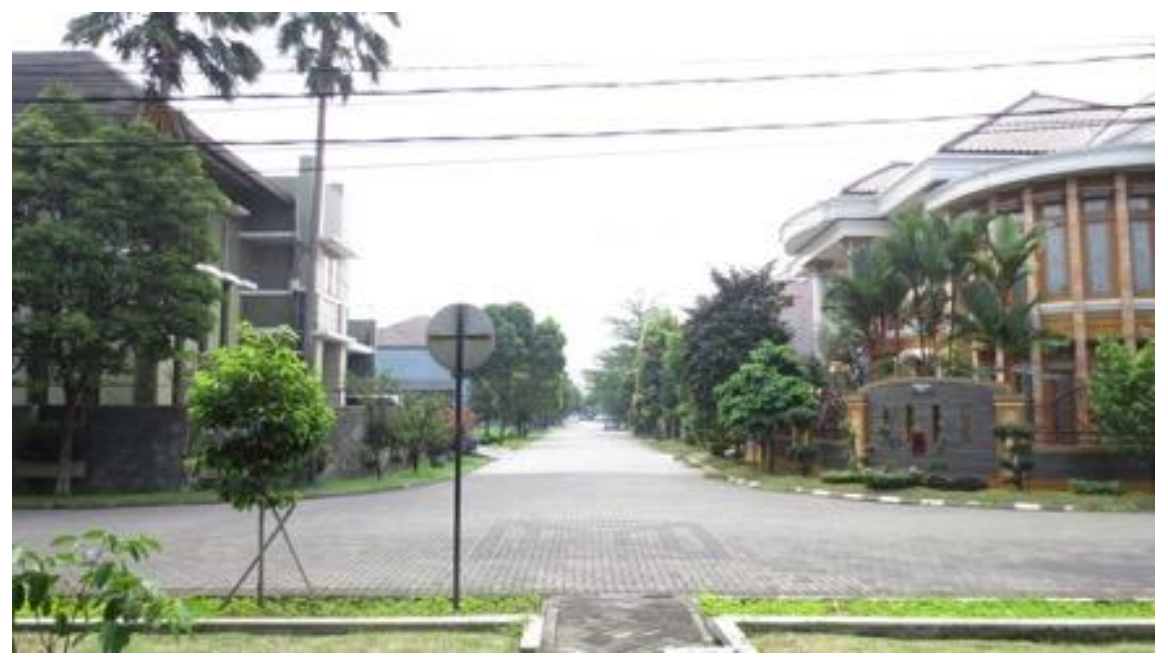

Gambar 7. Jarak Fisik Arsitektur Antar Rumah

\subsection{Pola Interaksi Penghuni Perumahan Cluster A}

Perkembangan kondisi sosial yang ada di Cluster A terjadi dan terbentuk akibat kondisi lingkungannya yang didiskusikan kedalam beberapa aspek. Aspek pertama yaitu status kependudukan. Penghuni yang sifat kependudukannya sementara hampir tidak pernah berinteraksi dengan penghuni lainnya, karakter penghuni seperti ini tidak pernah berusaha berbaur dengan kegiatan-kegiatan sosial yang diadakan pada lingkungan perumahan. Aspek kedua ruang publik (taman). Ruang publik dengan fasilitasnya diperlukan sebagai wadah untuk dapat menampung kegiatan penghuni, berinteraksi dengan komunitasnya. Namun pada taman Cluster A tidak disediakan fasilitas bermain anak yang layak, sehingga tidak jarang penghuni yang juga orang tua anak enggan mengajak anak-anaknya bermain, berinteraksi dengan anak-anak, penghuni lainnya.

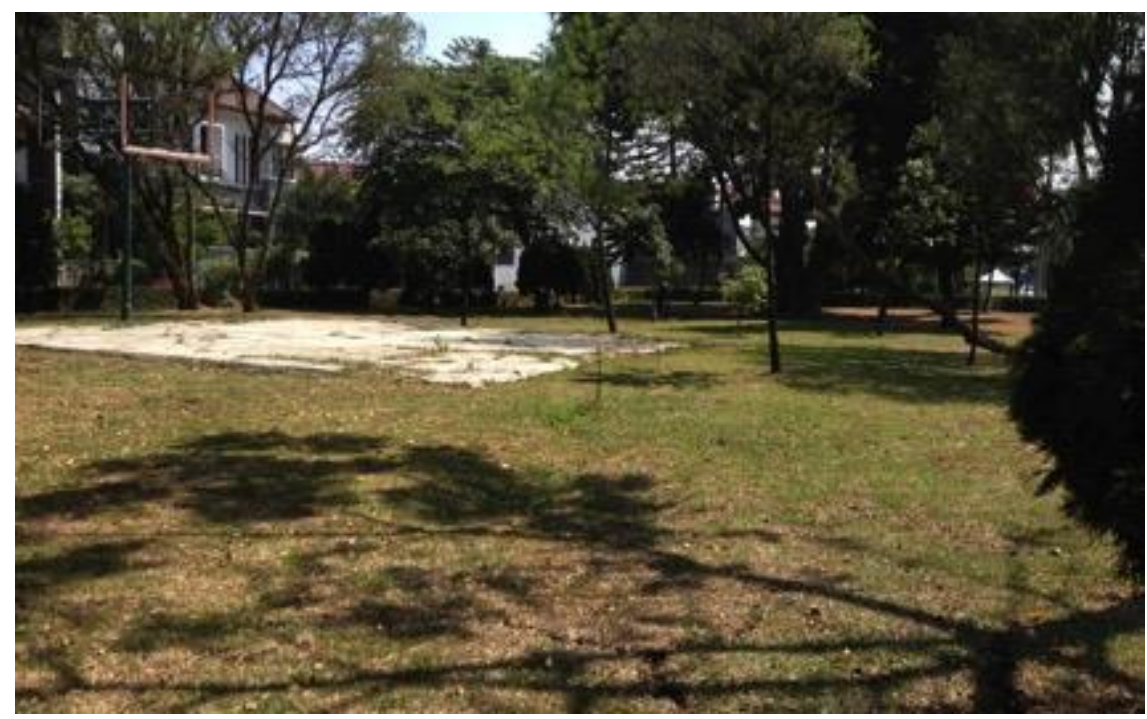

Gambar 8. Kondisi Fisik Taman Perumahan 


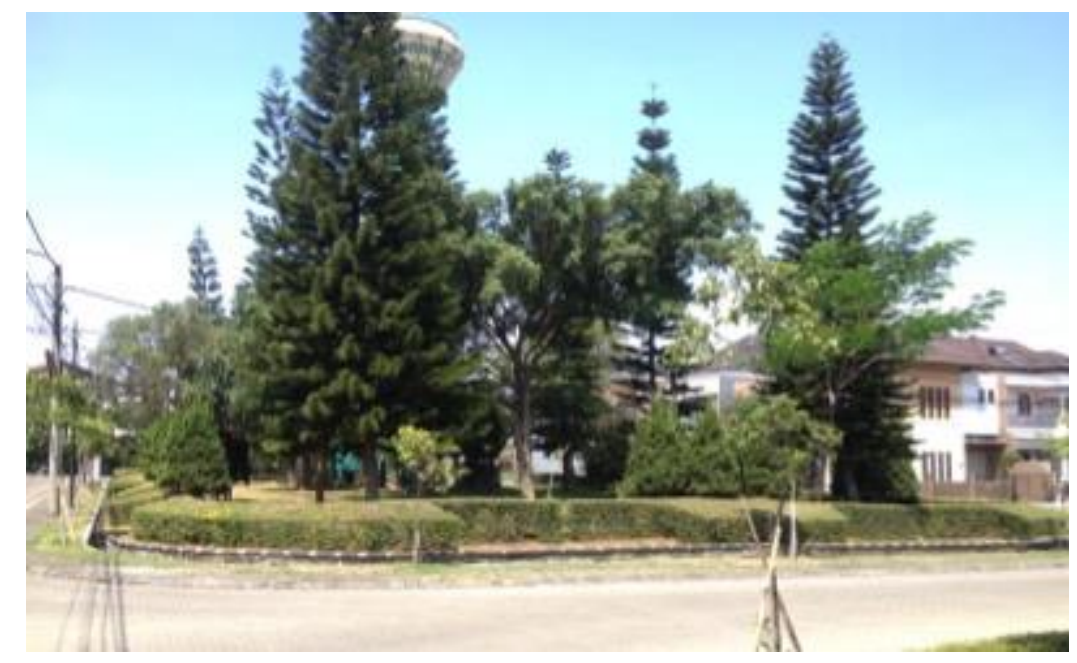

Gambar 9. Gambaran Aksesibilitas Taman

Kondisi taman yang tidak terawat, tanah yang retak-retak dan kering tidak layak dan membahayakan digunakan sebagai tempat berkegiatan penghuni. Terlihat juga fasilitas taman yang tidak terawat dengan baik menjadi faktor enggannya penghuni masuk dalam taman tersebut. Sayangnya kondisi ini tidak dilihat sebagai salah satu faktor yang menjauhkan warganya dari ruang publik sehingga tidak ada aktivitas penghuni pada ruang-ruang publik khususnya taman yang dapat menimbulkan interaksi antar penghuni. Tata letak dan akses taman juga merupakan unsur penting untuk menimbulkan kesan "mengundang" setiap penghuni yang ada disekitarnya untuk melakukan aktivitas, kegiatan-kegiatan bersama keluarga. Akses masuk kedalam taman tidak jelas, ditutupi tanaman-tanaman menjadikan konsep fungsi taman menjadi tidak jelas antara ruang hijau sebagai peneduh atau ruang terbuka yang mewadahi kegiatan. Fasilitas pendidikan juga merupakan peluang bagi penghuni untuk membentuk komunitas, namun justru hal tersebut tidak terjadi, dikarenakan fasilitas yang disediakan tidak berimbang, fasilitas pendidikan yang disediakan cenderung bagi komunitas penghuni dengan keyakinan mayoritas.

Status kependudukan penghuni yang merupakan penghuni sementara (PS) menjadi salah satu alasan bagi penghuni untuk tidak terlalu turut serta dalam setiap kegiatan-kegiatan yang dilakukan dalam satu lingkungan khususnya cluster A. Garis putus-putus melambangkan minimnya interaksi yang terjadi antar penghuni yang tetap dan penghuni sementara. Fasilitas pendidikan sebagai fasilitas sosial yang ada dalam perumahan terkesan hanya memihak bagi penghuni dengan kepercayaan mayoritas. Minimnya kepercayaan bagi penghuni minoritas didasarkan ideologi terhadap suatu kepercayaan agama sehingga bagi penghuni minoritas memilih untuk menggunakan fasilitas pendidikan diluar lingkungan perumahan. Hal ini sangat disayangkan karena fasilitas pendidikan justru merupakan salah satu wadah yang dapat membentuk jaringan, hubungan timbal balik dan kepercayaan bagi anak-anak sebagai generasi penerus pembangunan perilaku sosial dalam satu lingkungan perumahan.

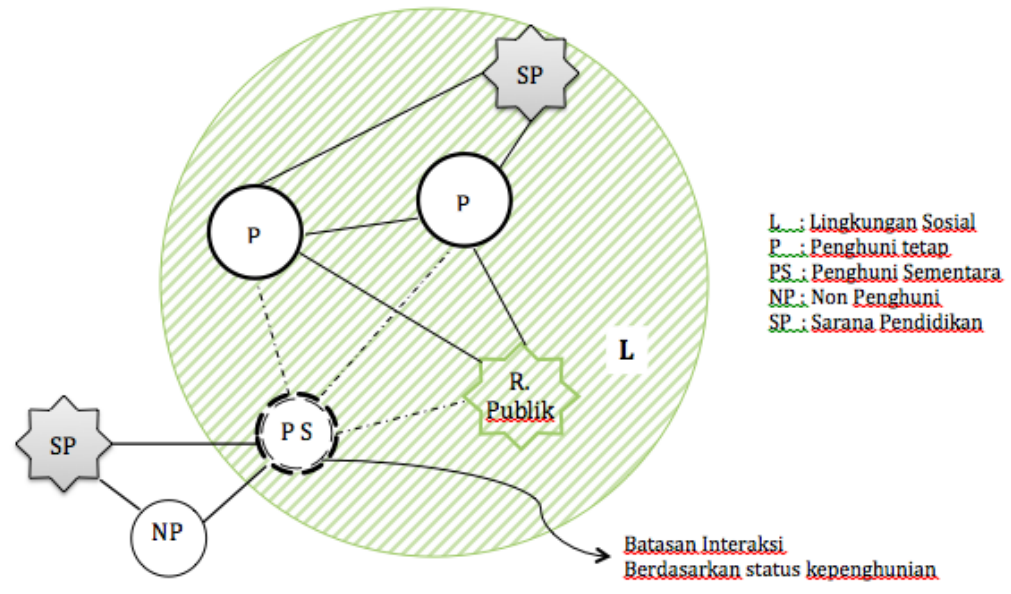

Gambar 10. Pola Hubungan Ketetanggaan Penghuni Cluster A. 


\subsection{Pola Interaksi Penghuni Dilihat Dari Sudut Pandang Lembaga Sosial (RT)}

Perkembangan kondisi sosial berdasarkan sudut pandang lembaga sosial pada Cluster A diuraikan kedalam beberapa aspek. Aspek pertama adalah interaksi sosial. Interaksi yang terjadi antar para penghuni lebih lekat terhadap bentuk interaksi yang bersifat disosiatif, terjadinya konflik antar penghuni merupakan suatu bentuk dari pertahanan teritorial masing-masing. Hal-hal yang menjadi pemicu terjadinya konflik antar penghuni adalah faktor budaya masing-masing penghuni berbeda dengan yang lainnya.

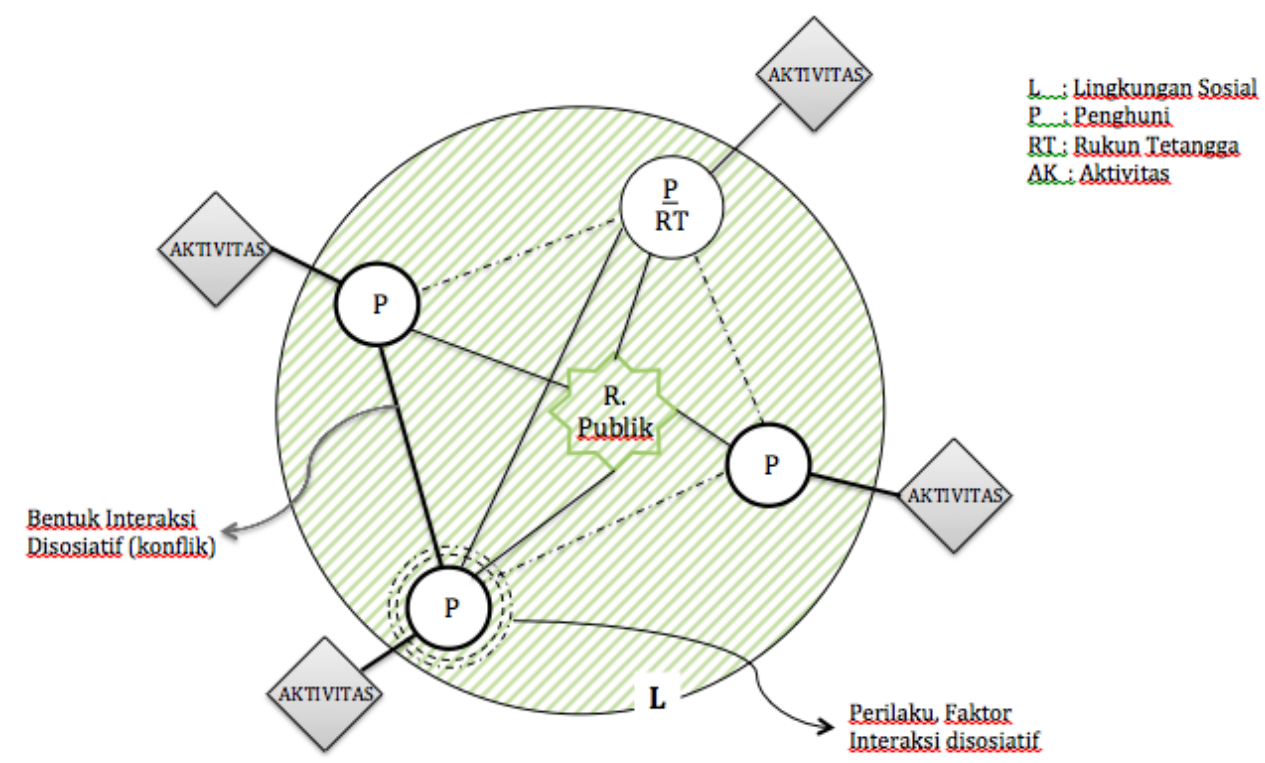

Gambar 11. Pola Hubungan Ketetanggaan Sudut Pandang Lembaga Sosial (RT)

Aspek kedua adalah waktu. Minimnya waktu bagi penghuni saat berada di lingkungan dihubungkan garis putus-putus melambangkan sulitnya lembaga sosial untuk mengadakan sistem pengendalian sosial, mengadakan kegiatan-kegiatan yang menuntut penghuni untuk turut serta. Fenomena lain yang terjadi pada lingkungan Cluster A adalah bentuk interaksi yang terjadi akibat konflik antar penghuni. Garis solid tebal menandakan bentuk interaksi yang terjadi secara terus menerus namun terjadi akibat pelanggaran terhadap norma-norma sosial yang diikuti oleh penolakan atau protes dari penghuni lainya yang mengganggu kenyamanan sehingga bentuk interaksi yang terjadi justru merusak kepercayaan penghuni untuk membentuk jaringan sosial yang dapat menimbulkan hubungan timbal balik yang positif.

\subsection{Pola Interaksi Kelompok Pengajian Penghuni Perumahan}

Tingkat rutinitas penghuni yang menjadi anggota kelompok pengajian memang menjadi tolak ukur solid atau tidaknya suatu komunitas. Nyatanya tingkat rutinitas yang cenderung tinggi sehingga waktu untuk berkumpul pada anggota komunitas pengajian menjadi semakin sedikit. Fenomena yang terjadi pada kelompok keagamaan lainnya yakni kelompok pengajian ibu-ibu justru terjadi perbedaan pola pikir. Dibedakan dalam dua kelompok yakni: kelompok penghuni real estate yang terbentuk secara tidak sengaja berdasarkan cluster besar yang hanya terdiri dari 20 anggota; kelompok penghuni real estate dari cluster kecil yang anggotanya cenderung lebih banyak karena anggotanya mengikutsertakan warga dari luar perumahan real estate. Faktor penyebab terjadinya perbedaan adalah enggannya salah satu kelompok keagamaan untuk bergabung bersama warga yang berasal dari luar perumahan. Hal ini merupakan salah satu ciri-ciri terjadinya ekslusivisme bagi penghuni real estate dan tidak adanya hubungan timbal balik dalam sebuah persamaan pada komunitas keagamaan.

\section{Kesimpulan}

\subsection{Praktik Interaksi Sosial - Arsitektur}

Hubungan sosial spasial pada salah satu perumahan real estate di Bandung tidak menunjang untuk menciptakan interaksi sosial penghuninya dalam konsep komunitas. Penghuni perumahan yang rutinitasnya sangat tinggi membutuhkan ruang yang nyaman, aman, tenang dan jauh dari keramaian. Sesuai dengan konsep perencanaannya yaitu nyaman, tenang dengan kemewahan tata ruang. Estetika arsitektur perumahan real estate memang sukses memfasilitasi kebutuhan tersebut, namun berpengaruh dalam menghambat perkembangan jaringan sosial di dalamnya. Penghuni perumahan cenderung dimanjakan dengan kondisi spasial yang tenang dan luas hingga menyebabkan penghuni jarang melakukan aktivitas-aktivitas fisik yang melibatkan praktik interaksi sosial 
terhadap penghuni lainnya. Fisik arsitektur perumahan real estate yang besar dan luas dengan memberikan pilihan tanah kavling bagi setiap penghuni yang dapat dimanfaatkan secara bebas dalam mendeskripsikan fisik arsitektur rumah sesuai pola perilaku dan konsep kenyamanan dan keamanan individu penghuninya tanpa harus mempertimbangkan konsep ketetanggaan. Kriteria jarak fisik antar rumah yang dipisah oleh jalan yang lebar, kondisi ini tidak mendukung kriteria jarak sosial (Hall.1966) sehingga dapat mempengaruhi psikologis manusia dalam mengurangi peluang untuk melakukan interaksi sosial. Penghuni perumahan real estate lebih senang menggunakan pagar yang tinggi (diukur dari skala perspektif mata manusia dewasa) untuk konsep keamanan dan kenyamanan, namun sadar atau tidak pagar-pagar tersebut ternyata berkontribusi mencegah kontak sosial antar penghuni dalam sebuah konsep ketetanggaan. Pada kenyatanya arsitektur perumahan real estate tidak dapat berkontribusi terhadap pembentukan respon psikologis penghuni untuk menjalankan pola interaksi sosial manusia didalamnya dalam konsep komunitas pada arsitektur perumahan dengan konsep neighborhood.

\subsection{Wadah Interaksi Sosial}

Secara umum kondisi fisik jalan sebagai salah satu ruang publik pada perumahan real estate cukup baik untuk mewadahi aktivitas yang dapat menimbulkan interaksi sosial antar penghuni. Namun justru bentuk kegiatan yang terjadi pada jalan di perumahan hanya berupa aktivitas proses dan aktivitas penting. Beberapa penghuni masih menggunakan jalan sebagai aktivitas pilihan (optional activities), dimana penghuni tersebut melakukan kegiatan yang berlangsung di pagi atau sore hari sekedar berjalan-jalan kaki hanya dilakukan pada keadaan dan waktu tertentu tergantung ketertarikan penghuni. Namun berdasarkan keadaannya, aktivitas-aktivitas yang terjadi pada ruang publik di perumahan tidak membentuk aktivitas sosial, tidak terjadi sekumpulan anak penghuni yang bermain bersama dan tidak terjadi percakapan antar tetangga dalam sebuah konsep neighborhood

\subsection{Karakter Interaksi Sosial Real Estate}

Karakter interaksi penghuni yang terjadi pada perumahan real estate belum dapat membentuk konsep komunitas yang solid. Perilaku penghuni perumahan real estate khususnya Cluster E, Cluster P, Cluster A belum dapat membentuk modal sosial bagi masing-masing penghuni. Kurangnya kontrol sosial yang dilakukan oleh penghuni beserta lembaga sosialnya menyebabkan struktur hubungan antar penghuni perumahan tersebut tidak menciptakan nilai-nilai baru yang dapat membentuk modal sosial. Pembentukan modal sosial lemah oleh proses-proses yang merusak kekerabatan, hubungan timbal balik antar penghuni seperti: perilaku/ kebiasaan pelanggaraan terhadap norma-norma oleh penghuni lainnya yang menyebabkan perselisihan/ konflik tanpa diikuti pengendalian sosial oleh penghuni lain dan lembaga sosial yang ada. Berdasarkan hasil pengamatan penelitian dalam arsitektur salah satu perumahan real estate di Bandung dan diperkuat dengan tinjauan teori yang telah dipaparkan pada bab-bab sebelumnya, maka disimpulkan beberapa unsur yang menjadi hambatan terbentuknya modal sosial bagi komunitas penghuni arsitektur perumahan, diantaranya: kepercayaan (trust), dilema waktu (time dilemma), ketergantungan sosial (social dependence), kepedulian sosial (social care), norma (norms) dan jejaring (network). Keenam unsur tersebut menjadi faktor lemahnya proses pembentukan modal sosial pada perumahan real estate. Apabila dikaji lagi penerapan dan eksistensi keenam unsur tersebut dalam sebuah arsitektur perumahan real estate, maka diharapkan mampu memperbaiki proses pembentukan modal sosial yang baik bagi penghuni perumahan real estate.

Untuk itu arsitektur perumahan real estate kedepannya perlu dikaji ulang dalam perencanannya. Tidak hanya melihat pada aspek komersial tetapi perlu memperhatikan aspek-aspek sosial dalam sebuah permukiman. Arsitektur rumah pada perumahan real estate harus menyikapi kebutuhan untuk dapat mengedepankan konsep neighborhood daripada kenyamanan individu. Bentuk fisik arsitektur, elemen-elemen rumah penghuni perumahan real estate harus mampu menciptakan keserasian, keterbukaan terhadap lingkungan sosial untuk menghasilkan hubungan timbal balik dan jaringan dalam konsep komunitas. Untuk pengembangan peran penghuni perumahan real estate dalam menciptakan komponen-komponen modal sosial pada perumahan yang heterogen, penulis menyarankan untuk dilakukan penelitian lanjutan dengan meneliti beberapa hal, yaitu: mengeksplorasi lebih jauh unsur-unsur yang menjadi lemahnya pembentukan modal sosial bagi masyarakat real estate untuk membentuk komunitas dan sejauh mana kontribusi pengembang sebagai fasilitator lingkungan perumahan dan permukiman yang heterogen dalam kontribusinya menciptakan lingkungan arsitektur yang tidak hanya mengutamakan aspek komersial-bisnis namun tetap beriringan dengan konsep neighborhood demi membentuk modal sosial bagi penghuni perumahan. 


\section{Daftar Pustaka}

Abrams, Charles. (1964). Man's Struggle for Shelter in an Urbanizing World. London: Cambridge.

Arcana, Putu Fajar., Prasetya, Lukas Adi (2006). Arsitek Tak Lebih dari Bidan. Kompas, Minggu 5 November 2006.

Barliana, M, Syaom. (2010). Arsitektur, Komunitas, dan Modal Sosial. Bandung: Metatekstur.

Bourdieu, P. (1986). The Forms of Capital, in John G. Richardson (EDT). Handbook of Theory and Research in the Sociology of education. New York: Greenwald Press.

Creswell. John W. (1998). Qualitative Inquiry and Research Design: Choosing Among Five Traditions. Sage Publications, Thousand Oak, London, New Delhi.

Christenson. J., Robinson J. (1980). Community development in America. Lowa: Iowa State University Press University of California.

Coleman, J. (1990). Foundations of Social Theory. Cambridge: Cambridge University Press.

Doxiadis, C. (1967). Ekistics: An Introduction to the Science of Human Settlements, Hutchinson, London.

Evans, G. W. (1982). Environmental stress. New York: Cambridge University Press.

Fukuyama, Francis. (1995). Trust; the Social Virtues and The Creation of Prosperity. New York: Free Press Paperbacks

Gehl, Jan. (1987). Life Between Buildings : Using Public Space. New York: Van Nostrand Reinhold.

Habermas, Jorgen. (1962). The Structural Transformation of the Public Sphere (trans. Thomas Burger, 1989). An Inquiry into Category of Bourgeois Society. MIT Press, Cambridge.

Hall, Edward T. (1966). The Hidden Dimension. New York: Doubleday and Company, Inc.

Lesser. E., (2000). Knowledge and Social Capital: Foundation and Application, Boston: Butterworth-Heinemann.

Putnam, D. Robert (2002). Democracies in Flux: The Evolution of Social Capital in Contemporary Society. New York, USA: Oxford University Press, Inc.

Rubenstein, Harvey M. (1992). Pedestrian Malls, Streetscapes, and Urban Spaces.

Taylor, R. B. (1982). The Neighborhood-Level Physical Environment And Stress-Related Impacts. In G. W. Evans (Ed.),Environment and Stress. New York, NY: Cambridge University Press.

Walmsley, DJ. \& Lewis, G. (1984). Human Geography; Behavioral Approaches. New York: Longman Inc.

Wenger, G Clare. (1990). The Special Role of Friends and Neighbors College of North Wales. Journal of Aging Studies, Volume 4, No. 2, Hal. 149-69. 